\title{
ANALYSIS OF CULTIVATED AND WILD USEFUL PLANTS IN THE HERBARIUM ZAGR OF THE FACULTY OF AGRICULTURE
}

\author{
Mihaela Britvec ${ }^{1}$, Sandro Bogdanović ${ }^{1}$, Ivana Vitasović Kosić ${ }^{1}$, \\ Ivica Ljubičić ${ }^{1}$, Dubravka Dujmović Purgar ${ }^{1}$, Miroslav Poje ${ }^{2}$ \& Vinka \\ Pavić ${ }^{3}$
}
${ }^{1}$ University of Zagreb Faculty of Agriculture, Department of Agricultural Botany, Svetošimunska cesta 25, 10000 Zagreb, Croatia

${ }^{2}$ University of Zagreb Faculty of Agriculture, Department of Ornamental Plants, Landscape Architecture and Garden Art, Svetošimunska cesta 25, 10000 Zagreb, Croatia

${ }^{3}$ Bukovac 62, 10000 Zagreb, Croatia

Britvec, M., Bogdanović, S., Vitasović Kosić, I., Ljubičić, I., Dujmović Purgar, D., Poje, M. \& Pavić, V.: Analysis of cultivated and wild useful plants in the ZAGR Herbarium of the Faculty of Agriculture. Nat. Croat., Vol. 27, No 2, 399-406, 2018, Zagreb.

The Herbarium ZAGR of the Faculty of Agriculture, University of Zagreb is one of the youngest in Croatia. The international acronym ZAGR was assigned by Index Herbariorum in 2013 when it was founded. Recently, in addition to the wild vascular flora, a collection of cultivated plants has been added to the herbarium material stored in the Herbarium ZAGR. Analysis has shown that 1737 herbarium specimens belong to the collection of cultivated and wild useful plants. There are 499 species and subspecies of useful plants, which are classified in 315 genera and 104 families. In total, the Herbarium ZAGR holds 18 useful species with cultivars. According to their employment, most taxa (326) can be used as medicine, 254 taxa can be used as food (166) or food additives (88), while bee plants include 172 taxa. The collection of cultivated and wild plants is available at http://herbarium.agr.hr/.

Key words: collection of cultivated plants, herbarium, ZAGR, Zagreb

Britvec, M., Bogdanović, S., Vitasović Kosić, I., Ljubičić, I., Dujmović Purgar, D., Poje, M. \& Pavić, V.: Analiza kultiviranih i samoniklih korisnih biljaka u ZAGR Herbariju Agronomskog fakulteta. Nat. Croat., Vol. 27, No 2, 399-406, 2018, Zagreb.

Herbarij Agronomskog fakulteta Sveučilišta u Zagrebu (ZAGR) jedan je od najmlađih herbarija u Hrvatskoj. ZAGR je međunarodni akronim koji mu je pri osnivanju 2013. godine dodijelio Index Herbariorum. Odnedavno herbarijska građa pohranjena u ZAGR Herbariju obuhvaća, pored samonikle vaskularne flore, također i zbirku kultiviranih biljaka. Analiza je pokazala da 1737 herbarijskih primjeraka pripada zbirci kultiviranih i samoniklih korisnih biljaka. Ustanovljeno je 499 vrsta i podvrsta korisnih biljaka koje su razvrstane u 315 rodova i 104 porodice. Ukupno je u ZAGR Herbariju zastupljeno 18 kultiviranih vrsta sa sortama. Prema načinu upotrebe, odnosno korištenju najviše svojti - njih 326 - može se koristiti u ljekovite svrhe, 254 svojte se mogu koristiti kao hrana (166) ili dodatak hrani (88), dok medonosnih biljaka ima 172 svojte. Zbirka kultiviranih biljaka i samoniklih korisnih biljaka dostupna je na http://herbarium.agr.hr/.

Ključne riječi: zbirka kultiviranih biljaka, herbarij, ZAGR, Zagreb 


\section{INTRODUCTION}

The origin of the modern herbarium is associated with the Italian botanist Luca Ghini, who is considered to be the first, in the mid-16th century, to have developed the practice of drying plants under pressure and putting the dried plant material on paper for documentation purposes (ARBER, 1938). Such early herbaria had the form of books and as part of private collections were available only to a small number of people (BRIDSON \& FORMAN, 1998). In the following period, from sheets bound into books, herbaria developed into collections of individual herbarium specimens (sheets) which were housed in cabinets (PraprotniK, 2015; CANTrill, 2018).

The numbers and sizes of herbarium collections have been increasing ever since, so that today there are approximately 3000 herbaria worldwide with more than 387 million herbarium specimens (THIERs, 2018). Herbaria represent a tremendous resource for researchers, as they form a permanent and well-documented record of plant distribution in space and time (Nualart et al., 2017; James et al., 2018).

However, until recently herbarium collections have been neither easily accessible nor linked. This situation has been completely changed by the computerization of herbarium collections, primarily the digitalization of herbarium specimens (CANTRILL, 2018).

Over time, the role of the herbarium has changed significantly. Starting from its initial role for the purpose of plant determination in using natural herbal remedies, altogether 72 possible herbarium usages have been documented (FUNK, 2003). Thus, the need to improve the knowledge of and to study cultivated plants has led to the development of cultivated plants collections, such as, for example, the Royal Horticultural Society Herbarium, Wisley (Whitenouse, 2014; Thiers, 2018).

Currently Croatia has 12 officially registered (listed in Index Herbariorum) herbarium collections (ThIERs, 2018). The Herbarium Croaticum (ZA) and the Herbarium of Ivo and Marija Horvat (ZAHO) are the two oldest and largest herbarium collections in Croatia (REŠETniK \& ŠEgOTA, 2018).

The Herbarium of the Faculty of Agriculture, University of Zagreb (ZAGR), was founded in 2013 and contains herbarium specimens of vascular plants, originating mostly from the Adriatic part of Croatia and the areas belonging to the Balkan Peninsula as well as from other Mediterranean countries (Bogdanović et al., 2016). Since 2014, herbarium material stored in the Herbarium ZAGR has also included a collection of cultivated plants, alongside wild flora.

The aim of this paper is to quantify and analyse the collection of cultivated and wild useful plants in the Herbarium ZAGR. The analysis of useful plants stored in the Herbarium ZAGR will include taxonomic analysis and analysis of their use patterns. Moreover, this paper will present the following characteristics of the collection: age of herbarium specimens, geographical origin of plant material, collection digitalization and collectors that contributed to the collection.

Additionally, one of the aims of the paper is to emphasize the importance of developing a broader knowledge about the cultivated plants and flora of Croatia since they are elements of the Croatian identity. Furthermore, the results obtained can be used in different disciplines in the field of agricultural and related sciences. 


\section{RESULTS}

\section{Characteristics of the collection of cultivated and wild useful plants}

The presence of cultivated and wild useful plants in the Herbarium ZAGR was determined and analysed largely based on the Useful Plants module, which is part of the Flora Croatica Database (Nikolić, 2018), and to a lesser extent according to data from literature (LIEBEREI \& REISDORFF, 2012).

As of the $19^{\text {th }}$ of January 2018, ZAGR Herbarium contained a total of 4870 herbarium specimens of vascular plants (Bogdanović, 2018). The analysis based on Useful Plants module showed that of the total number of herbarium specimens in the Herbarium ZAGR, 1737 herbarium specimens belong to the collection of cultivated and wild useful plants, i.e. to the collection of cultivated and wild plants that are or can be used for economic purposes.

\section{Taxonomic analysis}

The analysis revealed a total of 499 taxa of useful plants from 315 genera and 104 families. Of the 499 identified taxa of useful plants, 485 are angiosperms, mostly eudicots with 391 taxa, and there is a smaller part, of monocots, with 91 taxa and magnoliids with three taxa. Six species belong to the gymnosperms, and eight to the ferns.

Of the 104 families to which the useful plants belong, those with the most herbarium specimens are Poaceae (347), Lamiaceae (183), Fabaceae (173), Asteraceae and Rosaceae (141). Other families are represented by a smaller number of herbarium specimens $(\leq 100)$.

It has been found that 18 useful species in the Herbarium ZAGR are represented by cultivars (Tab. 1). The olive and the grapevine have the most cultivars - 10 each, and they are represented in the Herbarium ZAGR with 27 and 10 herbarium specimens, respectively. Fruit crops such as apple, pear, sour cherry, blueberry, peach, red and snow currant, gooseberry, walnut, cherry and aronia are also represented in the Herbarium ZAGR, but with a smaller number of cultivars. Wheat, barley, beans, lacy phacelia and basil are also represented by cultivars.

\section{Analysis of use patterns}

The use patterns of cultivated and wild useful plants in the Herbarium ZAGR were analysed according to data from literature (LiEberei \& ReisdorfF, 2012) and the Useful Plants module (Nikolić, 2018). The Economic Botany Data Collection Standard is commonly used in the analysis of plant use patterns (CoOK, 1995; NiKolić \& REŠETNIK, 2007). It contains 13 main groups of economic uses of plants: food, food additives, animal food, bee plants, invertebrate food, materials, fuels, social uses, vertebrate poisons, non-vertebrate poisons, medicines, environmental uses and gene sources (Cook, 1995). The concept of the Useful Plants module is largely consistent with the structure of the Economic Botany Data Collection Standard and includes all the above main groups of the economic use of plants, except for the group of gene sources (NiкоLić, 2013, 2018; PAvić, 2018).

Of the 499 identified useful plants species and subspecies, the highest number of taxa (326) can be used as medicines. They are followed by a group of 234 plants that may represent vertebrate poisons (Fig. 1). 
Tab. 1. List of cultivars of useful species and representation in herbarium specimens of the Herbarium ZAGR.

\begin{tabular}{|c|c|c|c|c|c|}
\hline Species & Cultivar & $\begin{array}{c}\text { No. of } \\
\text { specimens }\end{array}$ & Species & Cultivar & $\begin{array}{c}\text { No. of } \\
\text { specimens }\end{array}$ \\
\hline Aronia melanocarpa & 'Nero' & 2 & \multirow{5}{*}{ Prunus cerasus } & 'Ciganymeggy' & 3 \\
\hline \multirow{6}{*}{ Hordeum vulgare } & 'Favorit' & 3 & & 'Kereška' & 3 \\
\hline & 'Lukas' & 1 & & 'Maraska Brač 6' & 4 \\
\hline & 'Mombassa' & 2 & & 'Oblačinska' & 2 \\
\hline & \begin{tabular}{|l|} 
'Sandra' \\
\end{tabular} & 2 & & 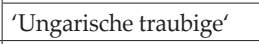 & 3 \\
\hline & 'Tatoo' & 2 & \multirow{2}{*}{ Prunus persica } & \begin{tabular}{|l|} 
'Cresthaven' \\
\end{tabular} & 2 \\
\hline & 'Titan' & 1 & & \begin{tabular}{|l|} 
'Redhaven' \\
\end{tabular} & 2 \\
\hline \multirow{2}{*}{ Juglans regia } & 'Geisenheim-1239' & 2 & \multirow{5}{*}{ Pyrus communis } & 'Boskova bočica' & 4 \\
\hline & 'Milotai $10^{\prime}$ & 2 & & 'Conference' & 2 \\
\hline \multirow{8}{*}{ Malus domestica } & ‘Elstar' & 2 & & \begin{tabular}{|c|} 
'Klapov ljubimac' \\
\end{tabular} & 2 \\
\hline & \begin{tabular}{|l} 
'Fuji' \\
\end{tabular} & 2 & & 'Packham's triumph' & 2 \\
\hline & 'Granny Smith' & 2 & & \begin{tabular}{|l|} 
'Viljamovka' \\
\end{tabular} & 2 \\
\hline & \begin{tabular}{|l|} 
'Idared' \\
\end{tabular} & 2 & Ribes niveum & 'Primus' & 2 \\
\hline & \begin{tabular}{|l} 
'Jonagold' \\
\end{tabular} & 3 & Ribes rubrum & 'Jonkheer van Tets' & 2 \\
\hline & \begin{tabular}{|l|} 
'Pinova' \\
\end{tabular} & 2 & Ribes uva-crispa & 'Rote Triumph' & 2 \\
\hline & 'Red Elstar' & 2 & \multirow{7}{*}{ Triticum aestivum } & 'Bologna' & 2 \\
\hline & 'Royal Gala' & 3 & & 'Energo' & 2 \\
\hline \multirow{3}{*}{ Ocimum basilicum } & 'Dark Opal' & 1 & & \begin{tabular}{|c|} 
'Graindor' \\
\end{tabular} & 2 \\
\hline & 'Genovese' & 1 & & 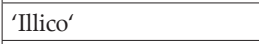 & 1 \\
\hline & \begin{tabular}{|l} 
'Sweet basil' \\
\end{tabular} & 3 & & 'Ingenio' & 2 \\
\hline \multirow{10}{*}{ Olea europaea } & 'Arbosana' & 2 & & 'Osječka šišulja' & 1 \\
\hline & 'Ascolana' & 2 & & 'Sofra' & 2 \\
\hline & \begin{tabular}{|l} 
'Istarska bjelica' \\
\end{tabular} & 3 & \multirow{2}{*}{ Vaccinium myrtillus } & 'Bluette' & 2 \\
\hline & \begin{tabular}{|l} 
'Itrana' \\
\end{tabular} & 3 & & 'Brigitta Blue' & 2 \\
\hline & \begin{tabular}{|l} 
'Lastovka' \\
\end{tabular} & 3 & \multirow{10}{*}{ Vitis vinifera } & 'Babić' & 1 \\
\hline & 'Leccino' & 2 & & 'Crljenak kaštelanski' & 1 \\
\hline & \begin{tabular}{|l|} 
'Leccio del Corno' \\
\end{tabular} & 3 & & \begin{tabular}{|l|} 
'Grk' \\
\end{tabular} & 1 \\
\hline & 'Pendolino' & 4 & & 'Kraljevina' & 1 \\
\hline & \begin{tabular}{|l|} 
'Picholine' \\
\end{tabular} & 2 & & \begin{tabular}{|l} 
'Malvazija dubrovačka' \\
\end{tabular} & 1 \\
\hline & 'Puntoža' & 3 & & 'Maraština' & 1 \\
\hline Phacelia tanacetifolia & 'Balo' & 1 & & 'Plavac mali' & 1 \\
\hline \multirow{4}{*}{ Phaseolus vulgaris } & 'Biser' & 1 & & \begin{tabular}{|l|} 
'Plavina' \\
\end{tabular} & 1 \\
\hline & 'Puter' & 1 & & \begin{tabular}{|l|} 
'Pošip' \\
\end{tabular} & 1 \\
\hline & 'Trešnjevac' & 2 & & 'Zlatarica blatska bijela' & 1 \\
\hline & 'Zelenčec' & 1 & & & \\
\hline \multirow{2}{*}{ Prunus avium } & \begin{tabular}{|l} 
Kordia' \\
\end{tabular} & 3 & & & \\
\hline & 'Regina' & 3 & & & \\
\hline
\end{tabular}

A total of 166 species and subspecies represented in the Herbarium ZAGR may be used as food, 88 as food additives, and 172 species and subspecies are bee plants. Furthermore, ZAGR Herbarium comprises 99 species and subspecies that can be used as animal food.

\section{Age of herbarium specimens}

Useful plants housed in ZAGR Herbarium were collected over the past 15 years. The most intensive collection activity regarding useful plants was during 2014 and 2015 when 224 and 563 herbarium samples of useful plants were collected annually. 


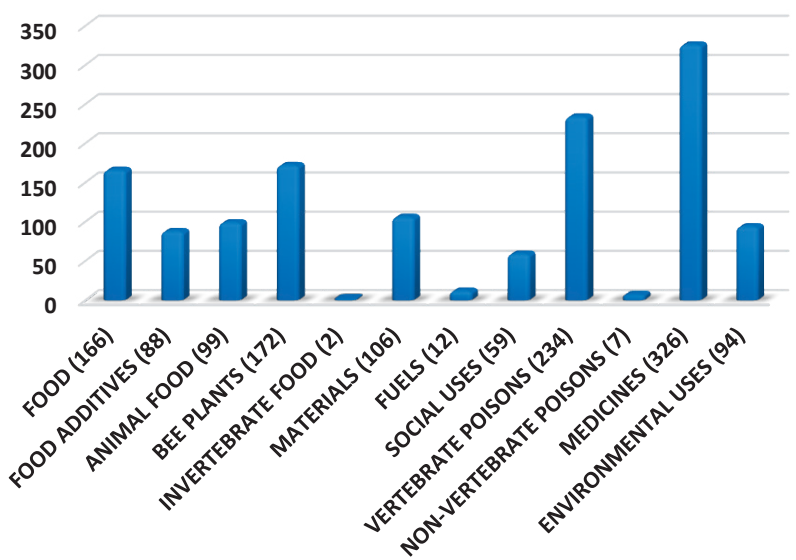

Fig. 1. Analysis of useful plants uses in the ZAGR Herbarium.

\section{Geographical origin of plant material}

The most herbarium specimens of wild useful plants (1720) were collected in Croatia, mostly in the Adriatic part of the country (1243) and a smaller share (477) in the continental part. Wild useful plants from Bosnia and Herzegovina, Montenegro, Italy and Serbia are represented in the collection by five or fewer herbarium specimens.

Cultivated plants were collected mostly at the experimental stations of the Faculty of Agriculture, University of Zagreb (Maksimir and Jazbina), at the experimental station of the Croatian Centre for Agriculture, Food and Rural Affairs in Donja Zelina and at the experimental estate of the Institute of Agriculture and Tourism in Poreč.

\section{Collectors who contributed to the forming of useful plants collection}

The collection of useful plants was created by 44 collectors, experts from Croatia and abroad and students from the University of Zagreb. The collectors who contributed most to the forming of the collection and are most often mentioned in the herbarium labels of useful plants are: Sandro Bogdanović (587 herbarium specimens), Ivana Vitasović Kosić (452), Ivica Ljubičić (408), Mara Vukojević (245), Dubravka Dujmović Purgar (195) and Martina Skendrović Babojelić (104).

\section{Digitization of ZAGR Herbarium}

Within the activities of two projects led by Sandro Bogdanović (Establishment of a collection of cultivated plants in the Herbarium ZAGR and Digitization of Herbarium ZAGR of the Faculty of Agriculture in Zagreb), the web page of the Virtual Herbarium ZAGR has been constantly updated with new herbarium insertions, and it was upgraded with a new module Cultivated plants (accessible at http://herbarium.agr.hr/cultivated_plants. $\mathrm{html}$ ). The digitization of herbarium specimens was begun in 2016 in order to make the collection available to a much wider audience. To date, over 2600 specimens have been scanned and are freely accessible at http://herbarium.agr.hr/ (BoGDANović et al., 2016). 


\section{CONCLUSION}

The Herbarium of the Faculty of Agriculture, University of Zagreb (ZAGR) contains 1737 herbarium specimens of cultivated and wild useful plants. A total of 499 taxa of useful plants were found and classified into 315 genera and 104 families. In total, the Herbarium ZAGR comprises 18 useful species with cultivars. The olive and the grapevine have the greatest number of cultivars (10 each).

According to use, 326 taxa can be used as medicine, followed by a group of 234 taxa which may represent vertebrate poisons. A total of 254 species and subspecies represented in ZAGR Herbarium may be used as food (166) or food additives (88), while bee plants include 172 species and subspecies. The Herbarium ZAGR comprises 99 species and subspecies that can be used as animal food.

The above results indicate that the Herbarium ZAGR provides a significant source of information on cultivated and wild useful plants. The digitization of herbarium specimens began in 2016 and is freely accessible at http://herbarium.agr.hr/.

Received October 23, 2018

\section{REFERENCES}

Arber, A., 1938: Herbals: their origin and evolution, 2nd ed. Cambridge University Press, Cambridge. Bogdanović, S. (ed.), 2018: Virtual Herbarium ZAGR. On-Line (http://herbarium.agr.hr/), Department of Agricultural Botany, Faculty of Agriculture, University of Zagreb. (Accessed: January 19 2018).

Bogdanović, S., Britvec, M., Dujmović Purgar, D., Ljubičić, I. \& Vitasović Kosić, I., 2016: Herbarium ZAGR of the Faculty of Agriculture (Zagreb, Croatia). Agriculturae conspectus scintificus 81(1), 1-5.

Bridson, D. \& Forman, L. (eds.), 1998: The Herbarium Handbook. Royal Botanic Gardens, Kew.

CANTRILL, D. J., 2018: The Australasian Virtual Herbarium: Tracking data usage and benefits for biological collections. Applications in Plant Sciences 6(2), e1026.

Соок, F. E. M., 1995: Economic Botany Data Collection Standard. Prepared for the International Working Group on Taxonomic Databases for Plant Sciences (TDWG). Royal Botanic Gardens, Kew.

Funk, V. A., 2003: 100 Uses for an Herbarium (Well at Least 72). American Society of Plant Taxonomists Newsletter 17(2), 17-19.

James, S. A., Soltis, P. S., Belbin, L., Chapman, A. D., Nelson, G., Paul, D. L. \& Collins, M., 2018: Herbarium data: Global biodiversity and societal botanical needs for novel research. Applications in Plant Sciences 6(2), e1024.

Lieberei, R. \& Reisdorff, C., 2012: Nutzpflanzen. Georg Thieme Verlag, Stuttgart, New York.

Nikolıć, T., 2013: Sistematska botanika: raznolikost i evolucija biljnog svijeta. Alfa d.d., Zagreb.

NiкоLIć, T. (ed.), 2018: Flora Croatica Database. On-Line (http://hirc.botanic.hr/fcd/), Department of Biology, Faculty of Science, University of Zagreb. (Accessed: January - June 2018).

Nikolić, T. \& RešEtnik, I., 2007: Plant uses in Croatia. Phytologia Balcanica 13(2), 229-238.

Nualart, N., Ibánez, N., Soriano, I. \& López-Pujol, J., 2017: Assessing the Relevance of Herbarium Collections as Tools for Conservation Biology. The Botanical Review 83(3), 303-325.

Pavić, V., 2018: Korisne biljke u herbariju Agronomskog fakulteta (ZAGR). Diplomski rad, Sveučilište u Zagrebu Agronomski fakultet.

Praprotnik, N., 2015: Botaniki, njihovo delo in herbarijske zbirke praprotnic in semenk v Prirodoslovnem muzeju Slovenije - The botanists, their work and herbarium collections of vascular plants in the Slovenian Museum of Natural History. Scopolia, Journal of the Slovenian Museum of Natural History 83-84, 1-414.

REŠETNIK, I. \& ŠEgOTA, V. (eds.), 2018: Virtual Herbarium ZA and ZAHO. On-Line (http://herbariumcroaticum.biol.pmf.hr/), Department of Biology, Faculty of Science, University of Zagreb. (Accessed: June 2018).

THIERS, B., 2018: Index Herbariorum: A global directory of public herbaria and associated staff. New York Botanical Garden's Virtual Herbarium. http://sweetgum.nybg.org/science/ih/ (Accessed: June 2018).

Whiтenouse, C. M., 2014: The Virtual Cultivated Plant Herbarium. Acta Horticulturae 1035, 99-103. 


\section{SAŽETAK}

\section{Analiza kultiviranih i samoniklih korisnih biljaka u ZAGR Herbariju Agronomskog fakulteta}

M. Britvec, S. Bogdanović, I. Vitasović Kosić, I. Ljubičić, D. Dujmović Purgar, M. Poje \& V. Pavić

Herbarij Agronomskog fakulteta Sveučilišta u Zagrebu (ZAGR) osnovan je 2013. godine i obuhvaća vaskularnu floru, porijeklom većinom iz jadranskog dijela Hrvatske.

Herbarijska građa pohranjena u ZAGR Herbariju obuhvaća, pored samonikle vaskularne flore, također i zbirku kultiviranih biljaka. Analizom je ustanovljeno ukupno 499 svojti (1737 herbarijskih primjeraka) kultiviranih i samoniklih korisnih biljaka. Također je ustanovljeno da je 18 korisnih vrsta u ZAGR Herbariju zastupljeno sa sortama. Najviše sorata - njih po 10, imaju maslina i vinova loza koje su u ZAGR Herbariju zastupljene s po 27, odnosno 10 herbarijskih primjeraka.

Od ustanovljenih 499 korisnih vrsta i podvrsta, prema načinu upotrebe, odnosno korištenju, najviše svojti - njih 326 - mogu se koristiti u ljekovite svrhe. Ukupno 166 vrsta i podvrsta može se upotrebljavati kao hrana, 88 kao dodatak hrani, dok medonosnih biljaka ima 172 vrste i podvrste. ZAGR Herbarij sadrži 99 vrsta i podvrsta koje se mogu koristiti kao hrana za životinje.

Kako bi zbirka kultiviranih i samoniklih korisnih biljaka ZAGR Herbarija bila dostupna široj javnosti, od 2016. godine provodi se digitalizacija herbarijskih primjeraka i znatan dio građe dostupan je na mrežnim stranicama http://herbarium.agr.hr/. 
